\title{
Nutrition Intakes and Nutritional Status of School Age Children in Ghana
}

\author{
Justina Serwaah Owusu ${ }^{1,2}$, Esi Komeley Colecraft ${ }^{2}$, Richmond Aryeetey $^{3}$, Joan A. Vaccaro ${ }^{1}$, \& Fatma G. \\ Huffman ${ }^{1}$
}

\begin{abstract}
${ }^{1}$ Department of Dietetics and Nutrition, Robert Stempel College of Public Health and Social Work, Florida International University, Miami, FL, USA

${ }^{2}$ Department of Nutrition and Food Science, University of Ghana, Accra, Ghana

${ }^{3}$ School of Public Health, University of Ghana, Accra, Ghana

Correspondence: Fatma G. Huffman, Department of Dietetics and Nutrition, Robert Stempel College of Public Health and Social Work, Florida International University, 11200 SW, 8th ST, AHC-5 Room 306, Miami, FL 33199, USA. Tel: 305-348-3788. E-mail: huffmanf@fiu.edu
\end{abstract}

Received: November 10, 2016 Accepted: December 12, $2016 \quad$ Online Published: February 6, 2017

doi:10.5539/jfr.v6n2p11

URL: http://dx.doi.org/10.5539/jfr.v6n2p11

\begin{abstract}
This paper compares nutrition intakes and nutritional status of school children from two public schools in neighbouring communities of Ghana with different school feeding programmes. One hundred and eighty-two caregiver and school-age child pairs were interviewed concerning socio-demographics, dietary practices, and food security in a cross-sectional design. The independent $t$-test was used to compare the contribution of the publicly funded Ghana School Feeding Programme and private School Feeding Programme meals to total daily nutrient intakes of the children. Predictors of nutritional status of the children were assessed using logistic regression models. The private school feeding programme contributed more energy, protein, and micronutrients as compared to the government school feeding programme. About two-thirds $(67.0 \%)$ of the children were stunted, underweight, or anaemic. Child's age was a significant predictor of stunting. Undernutrition was prevalent among children from both programmes. Improved quality of diet from the feeding programmes may contribute to addressing malnutrition in these children.
\end{abstract}

Keywords: nutrient intakes, nutritional status, school-age children, school feeding programmes, Ghana

\section{Introduction}

Undernutrition among school-age children (SAC) is a public health problem in developing countries (Best, Neufingerl, Van Geel, van den Briel, \& Osendarp, 2010). The most commonly reported nutrition problems among SAC include underweight and micronutrient deficiencies of iron, zinc, iodine, and vitamin A (Best et al., 2010). While nationwide data on the nutritional status of Ghanaian SAC are currently limited, a study in the Eastern region of the country found that $44 \%$ of the 645 rural SAC assessed were stunted, and $70 \%$ of them were anaemic (Fentiman, Hall, \& Bundy, 2001). More recently, a study in Ashanti region found 52.2\% of primary five pupils who were either participants or non-participants of Ghana School Feeding Programme (GSFP) were stunted and $46.5 \%$ of them underweight (Danquah, Amoah, Steiner-Asiedu, \& Opare-Obisaw, 2012). In Ghana, $13 \%$ and $19 \%$ of preschool age children are underweight and stunted, respectively (Ghana Statistical Service [GSS], Ghana Health Service [GHS], and Inner City Fund [ICF] Macro, 2015). Uncorrected, undernutrition among children in preschool age tracks into school-age (Bundy, 2009).

Undernutrition negatively affects children's health and capacity to perform in school. Researchers have reported a link between malnutrition and poor school attendance, intelligence quotient, school achievement, and morbidity among SAC (Ghazi, Isa, Aljunid, Tamil, \& Abdalqader, 2012; Mukudi, 2003; Omwami, Neumann, \& Bwibo, 2011; Schaible \& Kaufmann, 2007). Malnutrition among SAC in Africa has been linked to morbidity, hygienic practices, dietary intakes and family socioeconomic status (Herrador et al., 2014; Mesfin \& Berhane, 2015; Mwaniki \& Makokha, 2013; Ndukwu, Egbuonu, Ulasi, \& Ebenebe, 2013). Interventions for improving nutrition and health of SAC include deworming, health, nutrition and hygiene education, provision of portable water and sanitary latrines, micronutrient supplementation as well as school feeding programmes (World Food Programme [WFP] and United Nations Children's Fund [UNICEF], 2005). Well-designed school-feeding 
programmes tailored to specific needs of SAC have been effective in improving nutritional outcomes such as nutrient intake, physical growth, as well as micronutrient status (Adelman, Gilligan, \& Lehrer, 2008). Primarily, school-feeding programmes have been established to address hunger and its negative effect on the nutritional status and learning capacity of school-age children (WFP, 2015). Although, the provision of school meals to SAC cannot reverse all damage caused by early nutritional deficits (Bundy, 2009), many studies have reported nutritional and health benefits of school feeding programmes (Afridi, 2010; Ahmed, 2004; Arsenault et al., 2009; Musamali, 2007; Neervoort et al., 2013; Neumann, Murphy, Gewa, Grillenberger, \& Bwibo, 2007; Zeba, Martin Prevel, Some, \& Delisle, 2006). A systematic review of school-feeding programmes have reported improvements in weight, height in younger children (6-8 years), school attendance, mathematics performance, bone mineral density, arm muscle, concentrations of B - vitamins and behaviour among participants (Kristjansson et al., 2007). It has been recommended that school feeding meals should meet at least 30\% of energy and micronutrients need of children (Bhatia, 2013).

School-feeding programmes are implemented across the globe in both developing and developed nations (Bundy, 2009). The Ghana School Feeding Programme (GSFP) which started in 2005, aims to curb hunger and malnutrition through the provision of one nutritious hot meal prepared from locally-grown foodstuffs on school days (Ghana School Feeding Programme [GSFP], 2010). Longitudinal assessment of GSFP has reported improvements in school attendance, enrolment and educational performance among children (Abotsi, 2013). There is limited evidence, however, on nutrient intakes and nutritional status of SAC enrolled in school feeding programmes in Ghana. Additionally, there are limited studies that compare nutrient intakes of SAC in publicversus private-school feeding programmes feeding programmes. This paper presents evidence from a study which assessed dietary energy and nutrient intakes from school meals and nutritional status of school-age children enrolled in two school feeding programmes.

\section{Materials and Methods}

\subsection{Study Design and Population and Selection}

This was a comparative cross-sectional study with school children attending two public primary schools in neighbouring communities in the La- Nkwatanang Madina District in the Greater Accra region. These children were in classes 1 to 6 and between the ages of 6 and 12 years. One of the schools had a publicly funded School Feeding Programme (GSFP) and the other, a private School Feeding Programme (NSFP). Study procedures were explained to children in each class. Since there were more children at the GSFP site (300) compared to the NSFP site (125), all school-age children at GSFP site $(n=300)$ were asked to choose a concealed ballot for participation status: eligible or not eligible.

Caregivers of the children were verbally informed about the study at a Parent Teacher Association (PTA) meeting in each school. Caregivers provided signed informed consent for themselves and their children's participation in the study. Additionally, all participating children signed a child's assent form, prior to being interviewed. A total of 232 caregivers (112 from NSFP and 120 from GSFP) responded positively to permission slips sent out. Out of the total consenting respondents, complete interviews were obtained from 214 caregiverand child- pairs (100 children from NSFP and 114 from GSFP). Eighteen children were discovered to be ineligible (older than 12yr; or did not have no data on academic performance in the past school term). Thirty-two of the school-age children did not participate in the school feeding programmes and were eliminated in the final analysis. Their socio-demographic data was compared to those (182 children) participating in the school feeding programmes and there were no significant differences.

\subsection{Data Collection Procedures}

Data collection took place from January, 2013 through April 2013. Data collected included dietary intake assessment, anthropometry measurements and assessment of haemoglobin levels. Two sets of questionnaires were developed and pretested in a similar community in the La- Nkwatanang Madina District in the Greater Accra region prior to the study. Caregivers provided information on their personal and household characteristics, household food security and child morbidity, and these were recorded using a questionnaire. Another questionnaire was administered to the school-age children during break times at school and solicited information on personal characteristics and dietary habits throughout the day, both at school and at home.

\subsection{Dietary Intake Assessment}

The 24-hour recall method was used to collect information on all foods (including school meals) and beverages, except water, consumed by the school-age children on two non-consecutive school days. Days where the children were absent from school due to ill-health or other reason, or when the feeding programme did not serve 
meals to any of the children were excluded from the recall days. In recalling foods consumed in the past 24-hours, the SAC were also asked to indicate the time and source of the food (whether purchased, home-made, or school-meal) for each eating event. Household measures and wooden food models were used to help children estimate quantities of foods consumed. For foods that the children reported purchasing from food vendors within the school compound or the community, the cost of food was obtained and the same quantities were purchased and weighed to estimate the quantities consumed by the children. Additionally, a sample of foods served to children by the feeding programmes were weighed daily over a five-day period to estimate the average serving size provided. Caregivers or older siblings helped in estimating the quantities of foods eaten at home for children younger than seven years old who could not estimate their food quantities.

\subsection{Assessment of Anthropometry and Haemoglobin Levels}

Height and weight measurements were completed for SAC using standard procedures (Centers for Disease Control and Prevention [CDC], 2015). The children's heights were measured to the nearest $0.1 \mathrm{~cm}$ with a Tanita HR-200 stadiometer and a Tanita BWB 800 weighing scale was used to take their weights to the nearest $0.1 \mathrm{~kg}$. Height and weight measurements were taken in duplicates and the average recorded. Haemoglobin levels of 54\% $(\mathrm{n}=99 ; 48$ from GSFP site and 51 from NSFP site) of the school-age children were assessed. Selection of children was done by choosing every other child from the list of participants in order of interview. However, three children who did not want to participate in haemoglobin testing were replaced from the sample. Two to three drops of blood, enough to fill a cuvette, was obtained from each child using the finger prick method by a professional phlebotomist (Inter Tribal Council of Arizona [ITCA], 2012). The haemoglobin level of each participant was measured in grams per decilitre using the $\mathrm{Hb} 201^{+}$Hemocue machine.

\subsection{Statistical Analysis}

SPSS version 16. 0 was used for data management and analysis. Dietary information was converted to energy and nutrients using the Research to Improve Infant Nutrition and Growth (RIING) Project Nutrient Database available at Department of Nutrition and Food science, University of Ghana. Anthropometric data of weight and height were converted to height for age $\mathrm{Z}$ scores (HAZ) and BMI for age Z scores (BAZ) using WHO Anthro Plus version 10.4. Haemoglobin levels of school-age children were categorized by anaemia status (anaemic vs. non-anaemic) based on age specific cut offs set by WHO (World Health Organization [WHO], 2011). Dietary diversity scores (DDS) were also calculated using the Food and Agriculture Organization (FAO) guideline (Kennedy, Ballard, \& Dop, 2011). Descriptive statistics was used to summarize categorical and continuous variables. The independent $t$-test was used to compare the contribution of NSFP and GSFP meals to intakes of school-age children and total daily intakes of school-age children. Predictors of nutritional status of SAC were assessed using logistic regression models. Level of significance was set at $P<0.05$.

\section{Results}

\subsection{Socio-Demographic and Household Characteristics of School Age Children and Their Caregivers in the Study}

The mean age of caregivers was $41 \pm 11$ years and most of them (68.1\%) were the children's biological parents (Table 1). The majority were either Ga/Ga-Adangme or Ewe ethnicity $(61.6 \%)$ and $70 \%$ had completed at least junior secondary or middle school. Caregivers were mainly traders $(62.6 \%)$ and the majority were married (81.3\%). Overall, the most common economic activities of the caregiver's spouses were masonry, carpentry, electricians, driving, and tailoring (vocational employment). Majority $(70.2 \%)$ of caregivers reported a household income of 500 Ghana cedis (USD 256 in 2013) or less. The average household size was $6 \pm 2$ members comprising of a mean of $3 \pm 1$ adults and $4 \pm 2$ children (<18yrs). Caregivers of school-age children in the GSFP and NSFP had similar socio-demographic characteristics, except that the majority (76.5\%) of spouses of caregivers of the SAC in the GSFP were in vocational employment compared to less than 50\% of spouses of caregivers of the NSFP children $(P=0.002)$. The mean age of the SAC was $10 \pm 2$ years and the majority were in classes one through three (Table 2). About 55\% of the children were female and Christianity was the most common religion reported. A little over $50 \%$ of the children lived in the same community where the school was located, and were living with both parents. The majority of the children received money for school from their parents; those who were given money received $0.80 \pm 0.36$ Ghana cedis (USD $0.41 \pm 0.18$ in 2013) daily. There were no significant differences in the background characteristics of SAC in the GSFP and the NSFP.

\subsection{Dietary Habits, Nutrient Intakes and Nutritional Status}

During school days the children ate an average of $4 \pm 1$ times (inclusive of meals and snacks), per day (Table 3). More than one- half $(56 \pm 16 \%)$ of the children's eating events on school days were consumed at home. An 
average of $50.3 \pm 18 \%$ of the children's eating events on school days was home-prepared and $25 \pm 4 \%$ was a meal from the school feeding programmes. Figure 1 shows the food groups consumed in past 24 hours (average of 2 non-consecutive 24hour recalls). Nearly all the SAC had consumed foods from grains, roots and tubers, fish and meat, and fruits and vegetables, over the two days of recall. Less than $20 \%$ of the children consumed dark green vegetables and organ meat was the least consumed food group. The mean dietary diversity score for school-age children diet was $5 \pm 1$ food groups.

Compared to children in the GSFP, children in the NSFP had significantly higher intakes of energy $(2413 \pm 626$ kcal vs. $1988 \pm 627 \mathrm{kcal}$; $\mathrm{P}<0.001)$, protein $(63 \pm 17 \mathrm{~g}$ vs. $53 \pm 19 \mathrm{~g} ; \mathrm{P}<0.001)$ and zinc $(10 \pm 3 \mathrm{mg}$ vs. $9 \pm 3 \mathrm{mg}$; $\mathrm{P}=0.004$ ) (Table 4). Amounts of iron, calcium, vitamin $\mathrm{A}$ and vitamin $\mathrm{C}$ consumed were similar for the two groups. GSFP meals contributed $12 \%$ to $18.1 \%$ of the total energy and nutrient intakes of the children; whereas, NSFP meals contributed from $17 \%$ up to $30 \%$ of the total energy and nutrient intakes of the children (Table 5). With the exception of iron, where the contribution from meals by both types of programmes was similar, meals provided through the NSFP contributed significantly more energy $(28 \pm 10 \%$ vs. $16.2 \pm 7 \% ; P<0.001)$, protein $(24.6 \pm 9 \%$ vs. $13.3 \pm 7 \% ; P<0.001)$ and micronutrients, specifically zinc $(P<0.001)$, calcium $(P<0.001)$, vitamin $\mathrm{C}(P<0.001)$, and Vitamin A $(P=0.042)$ to the children's total energy intakes compared to meals provided through the GSFP.

About $28 \%$ of the school-age children had low haemoglobin levels indicative of anaemia (Figure 2). Approximately $48 \%$ of the children were stunted and $35 \%$ had low BMI-for-age or were thin and about $1 \%$ were overweight. Sixty seven percent of the school-age children in the study had at least one nutritional deficit (including either anaemia, stunting, or thinness). A logistic regression model for stunting is shown in Table 6. Energy intake, type of feeding programme child was enrolled in, and food security status were not associated with stunting. Children under 10 years had lower odds of stunting as compared to children who were 10 years or older [OR $=0.47(0.24,0.91) p=0.025]$. Sex was marginally significant with a trend for boys to have higher odds of stunting as compared to girls. 
Table 1. Socio-demographic and Household characteristics of caregivers of Participants Government School Feeding Programme (GSFP) and NGO School Feeding Programme (NSFP)

\begin{tabular}{|c|c|c|c|c|c|c|c|}
\hline \multirow[b]{2}{*}{ Characteristics } & \multicolumn{2}{|c|}{ Total $(N=182)$} & \multicolumn{2}{|c|}{$\operatorname{NSFP}(N=98)$} & \multicolumn{2}{|c|}{$\operatorname{GSFP}(N=84)$} & \multirow[t]{2}{*}{$P$} \\
\hline & $n$ & $\%$ & $n$ & $\%$ & $n$ & $\%$ & \\
\hline Mean Age (yrs) & 41 & & 40 & & 42 & & 0.331 \\
\hline SD & 11 & & 12 & & 11 & & \\
\hline \multicolumn{8}{|l|}{ Relationship to child } \\
\hline Biological parent & 124 & 68.1 & 70 & 71.4 & 54 & 64.3 & 0.303 \\
\hline Other relative $^{1}$ & 58 & 31.9 & 28 & 28.6 & 30 & 35.7 & \\
\hline \multicolumn{8}{|l|}{ Ethnicity } \\
\hline $\mathrm{Ga} / \mathrm{Ga}$ - Adangme & 56 & 30.8 & 32 & 32.7 & 24 & 28.5 & 0.313 \\
\hline Ewe & 56 & 30.8 & 34 & 34.7 & 22 & 26.2 & \\
\hline Akan & 40 & 22.0 & 17 & 17.3 & 23 & 27.4 & \\
\hline Northern ethnicity & 30 & 16.5 & 15 & 15.3 & 15 & 17.9 & \\
\hline \multicolumn{8}{|l|}{ Formal education completed } \\
\hline None & 33 & 18.3 & 17 & 17.7 & 16 & 19.0 & 0.702 \\
\hline Primary & 46 & 25.6 & 26 & 27.1 & 20 & 23.8 & \\
\hline JHS/Middle school & 80 & 44.4 & 45 & 46.9 & 35 & 41.7 & \\
\hline$>\mathrm{JHS}$ & 21 & 11.7 & 8 & 8.3 & 13 & 15.5 & \\
\hline \multicolumn{8}{|l|}{ Occupation } \\
\hline Trader & 114 & 62.6 & 62 & 63.3 & 52 & 61.9 & 0.525 \\
\hline Vocational Occupation & 19 & 10.4 & 8 & 8.2 & 11 & 13.1 & \\
\hline None & 15 & 8.3 & 7 & 7.1 & 8 & 9.5 & \\
\hline Other $^{2}$ & 34 & 18.7 & 21 & 21.4 & 13 & 15.5 & \\
\hline \multicolumn{8}{|l|}{ Marital status } \\
\hline Married & 148 & 81.3 & 82 & 83.7 & 66 & 78.6 & 0.379 \\
\hline Single /Divorced/Widowed & 34 & 18.7 & 16 & 16.3 & 18 & 21.4 & \\
\hline \multicolumn{8}{|c|}{ Spouse's (Paternal) education level* } \\
\hline$\leq$ Primary & 36 & 23.7 & 21 & 25.0 & 15 & 22.1 & 0.165 \\
\hline JHS/Middle school & 75 & 49.3 & 36 & 42.9 & 39 & 57.3 & \\
\hline > JHS/Middle school & 41 & 27.0 & 27 & 32.1 & 14 & 20.6 & \\
\hline \multicolumn{8}{|l|}{ Spouse's occupation* } \\
\hline Vocational & 91 & 59.9 & 39 & 46.4 & 52 & 76.5 & 0.002 \\
\hline Professional & 18 & 11.8 & 13 & 15.3 & 5 & 7.4 & \\
\hline None & 4 & 2.6 & 2 & 2.4 & 2 & 2.9 & \\
\hline Other ${ }^{3}$ & 39 & 35.7 & 32 & 37.6 & 9 & 13.2 & \\
\hline \multicolumn{8}{|l|}{ Monthly household income } \\
\hline$\leq \mathrm{GH} \phi 500(\leq \mathrm{USD} 256)$ & 127 & 70.2 & 63 & 64.9 & 64 & 76.2 & 0.099 \\
\hline \multirow[t]{2}{*}{$>$ GH $₫ 500(>$ USD 256) } & 54 & 29.8 & 34 & 35.1 & 20 & 23.8 & \\
\hline & Mean & SD & Mean & SD & Mean & SD & \\
\hline Household size & 6 & 2 & 6 & 2 & 6 & 2 & 0.390 \\
\hline No. of adults & 3 & 1 & 3 & 1 & 3 & 1 & 0.969 \\
\hline No. of children $(<18 \mathrm{yrs})$ & 4 & 2 & 4 & 2 & 4 & 2 & 0.649 \\
\hline
\end{tabular}

NSFP: Non-Government School Feeding Programme, GSFP: Government School Feeding Programme.

${ }^{1}$ Other relatives include aunts, uncles, siblings, grandparents, step parents and non-relatives; ${ }^{2}$ Other includes stone winnower, farmer and professional workers; ${ }^{3}$ Other includes maintenance/security workers, stone winnower, trader, pensioner, susu collector and farmer.

* Paternal caregiver. 
Table 2. Background characteristics of school age children participating in NSFP and GSFP

\begin{tabular}{|c|c|c|c|c|c|c|c|}
\hline \multirow{2}{*}{ Characteristics } & \multicolumn{2}{|c|}{ Total $(N=182)$} & \multicolumn{2}{|c|}{$\operatorname{NSFP}(N=98)$} & \multicolumn{2}{|c|}{$\operatorname{GSFP}(N=84)$} & \multirow[t]{2}{*}{$P$} \\
\hline & $n$ & $\%$ & $n$ & $\%$ & $n$ & $\%$ & \\
\hline Mean Age (yrs) & 10 & & 10 & & 10 & & 0.888 \\
\hline SD & 2 & & 2 & & 2 & & \\
\hline \multicolumn{8}{|l|}{ Class } \\
\hline 1 to 3 & 112 & 61.5 & 57 & 58.2 & 55 & 65.5 & 0.312 \\
\hline 4 to 6 & 70 & 38.5 & 41 & 41.8 & 29 & 34.5 & \\
\hline \multicolumn{8}{|l|}{ Sex } \\
\hline Female & 100 & 54.9 & 51 & 52.0 & 49 & 58.3 & 0.395 \\
\hline Male & 82 & 45.1 & 47 & 48.0 & 35 & 41.7 & \\
\hline \multicolumn{8}{|l|}{ Religion } \\
\hline Christian & 163 & 89.6 & 87 & 88.8 & 76 & 90.5 & 0.708 \\
\hline Islam & 19 & 10.4 & 11 & 11.2 & 8 & 9.5 & \\
\hline \multicolumn{8}{|l|}{ Residence } \\
\hline Within School's Community & 99 & 54.4 & 50 & 51.0 & 49 & 58.3 & 0.323 \\
\hline Outside School's Community & 83 & 45.6 & 48 & 49.0 & 35 & 41.7 & \\
\hline \multicolumn{8}{|l|}{ Lives with } \\
\hline Both parents & 98 & 53.8 & 55 & 56.1 & 43 & 51.2 & 0.456 \\
\hline Single parent & 34 & 18.7 & 16 & 16.3 & 18 & 21.4 & \\
\hline Other relatives ${ }^{1}$ & 50 & 27.5 & 27 & 27.5 & 23 & 27.4 & \\
\hline \multicolumn{8}{|l|}{ Received money for school } \\
\hline No & 30 & 16.5 & 14 & 14.3 & 16 & 19.0 & 0.388 \\
\hline \multirow[t]{2}{*}{ Yes } & 152 & 83.5 & 84 & 85.7 & 68 & 81.0 & \\
\hline & Mean & SD & Mean & SD & Mean & SD & \\
\hline Money received for food on school days (GH $\phi$ ) & 0.80 & 0.36 & 0.79 & 0.31 & 0.70 & 0.31 & 0.081 \\
\hline
\end{tabular}

NSFP: Non-Government School Feeding Programme, GSFP: Government School Feeding Programme.

${ }^{1}$ Other relatives include aunts, uncles, siblings, grandparents and non-relatives.

Table 3. Dietary habits of school children on school days

\begin{tabular}{lll}
\hline Characteristics & Mean & SD \\
\hline $\begin{array}{l}\text { Frequency of eating events } \\
\text { Location for eating events (\%) }\end{array}$ & 4 & 1 \\
$\quad$ Home & 56 & 16 \\
$\quad$ School & 38 & 13 \\
$\quad$ Food vendor's place & 6 & 13 \\
Source of food (\%) & & \\
$\quad$ Home prepared & 50.3 & 18 \\
$\quad$ School feeding programme & 25 & 4 \\
$\quad$ Street food & 18 & 20 \\
$\quad$ School compound vendor & 8 & 12 \\
\hline
\end{tabular}


Table 4. Daily total intakes of energy and selected nutrients of Participants of NSFP and GSFP (2-day 24-hour recall)

\begin{tabular}{|c|c|c|c|c|c|c|c|c|}
\hline & \multirow[t]{2}{*}{ DRI } & \multicolumn{2}{|c|}{$\begin{array}{l}\text { Total } \\
(N=180)\end{array}$} & \multicolumn{2}{|c|}{$\begin{array}{l}\text { NSFP } \\
(N=97)\end{array}$} & \multicolumn{2}{|c|}{$\begin{array}{l}\text { GSFP } \\
(N=83)\end{array}$} & \multirow[t]{2}{*}{$P$} \\
\hline & & Mean & SD & Mean & SD & Mean & SD & \\
\hline Energy (kcal) & $1428-2341$ & 2217 & 660 & 2413 & 626 & 1988 & 627 & $<0.001$ \\
\hline Protein (g) & $19-34$ & 58 & 19 & 63 & 17 & 53 & 19 & $<0.001$ \\
\hline Fats (g) & ND & 53 & 30 & 55 & 26 & 50 & 36 & 0.302 \\
\hline Iron (mg) & $8-10$ & 25 & 8 & 25 & 7 & 25 & 10 & 0.617 \\
\hline Zinc (mg) & $5-8$ & 9 & 3 & 10 & 3 & 9 & 3 & 0.004 \\
\hline Calcium (mg) & $800-1300$ & 384 & 173 & 389 & 162 & 378 & 186 & 0.687 \\
\hline Vitamin A (IU) & $1333-2000$ & 947 & 1230 & 977 & 1035 & 912 & 1430 & 0.723 \\
\hline Vitamin C (mg) & $25-45$ & 87 & 50 & 93 & 49 & 81 & 50 & 0.106 \\
\hline
\end{tabular}

Table 5. Mean percent contribution of school meals to the total daily energy and nutrients of school-age children by type school feeding programme

\begin{tabular}{llllcl}
\hline & \multicolumn{2}{l}{ GSFP $(\boldsymbol{N}=\mathbf{8 3})$} & \multicolumn{2}{l}{ NSFP $(\boldsymbol{N}=97)$} & $\boldsymbol{P}$ \\
& Mean & SD & Mean & SD & \\
\hline Energy & 16.2 & 7 & 28.0 & 10 & $<0.001$ \\
Protein & 13.3 & 7 & 24.6 & 9 & $<0.001$ \\
Fats & 13.3 & 11 & 22.3 & 12 & $<0.001$ \\
Iron & 18.1 & 10 & 20.3 & 8 & 0.109 \\
Zinc & 15.7 & 8 & 26.3 & 10 & $<0.001$ \\
Calcium & 12.5 & 9 & 22.4 & 11 & $<0.001$ \\
Vitamin A & 12.6 & 14 & 17.4 & 18 & 0.042 \\
Vitamin C & 16.1 & 13 & 30.2 & 18 & $<0.001$ \\
\hline
\end{tabular}

Table 6. Socio-demographic characteristics and dietary variables associated with stunting levels among children

\begin{tabular}{|c|c|c|c|c|}
\hline & $N$ & Odds Ratio & 95\% Confidence Interval & $P$ \\
\hline \multicolumn{5}{|l|}{ Child's age } \\
\hline$<10 \mathrm{yrs}$ & 63 & 0.468 & \multirow[t]{2}{*}{$0.241,0.908$} & 0.025 \\
\hline$\geq 10 \mathrm{yrs}$ (reference) & 114 & 1.000 & & \\
\hline \multicolumn{5}{|l|}{ Child's gender } \\
\hline Male & 79 & 1.784 & \multirow[t]{2}{*}{$0.960,3.314$} & 0.067 \\
\hline Female (reference) & 98 & 1.000 & & \\
\hline \multicolumn{5}{|l|}{ Food Security status } \\
\hline Food secured & 123 & 0.773 & \multirow[t]{2}{*}{$0.398,1.503$} & 0.448 \\
\hline Food Insecure (reference) & 54 & 1.000 & & \\
\hline Energy (kcal) & 177 & 1.000 & $0.999,1.000$ & 0.089 \\
\hline \multicolumn{5}{|l|}{ Type of feeding programme } \\
\hline GSFP & 82 & 0.823 & 0.424 & 0.563 \\
\hline NSFP (reference) & 95 & 1.000 & & \\
\hline
\end{tabular}




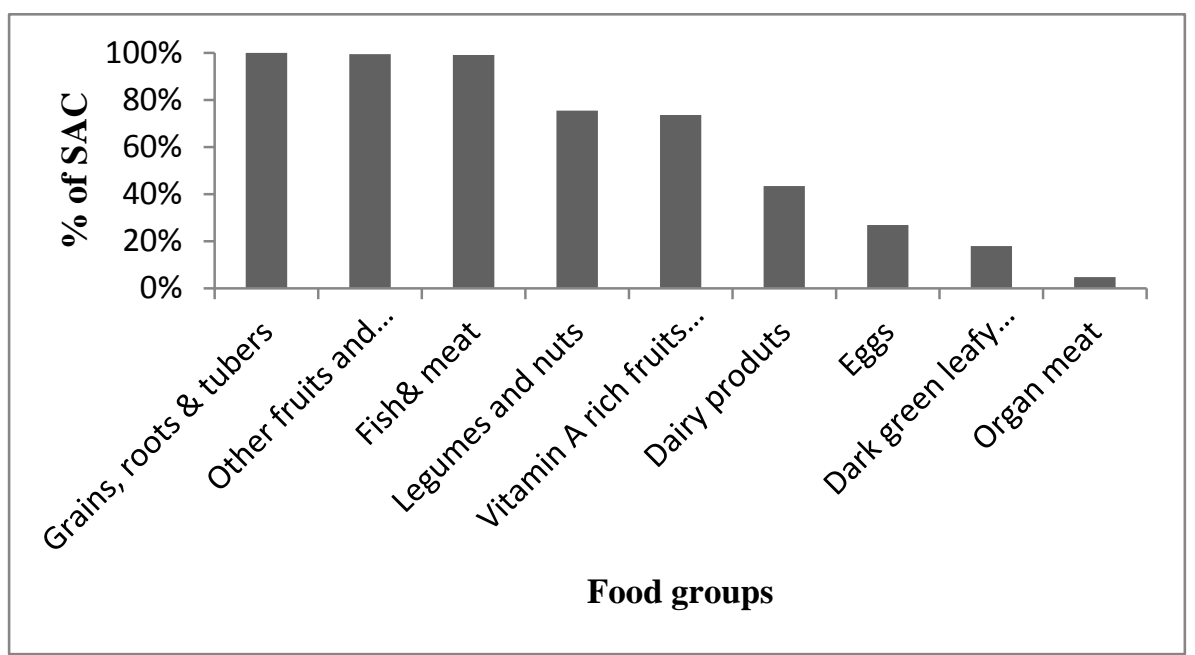

Figure 1. Food groups consumed by school-age children in the past 24 Hours (2-day 24 Hour recall)

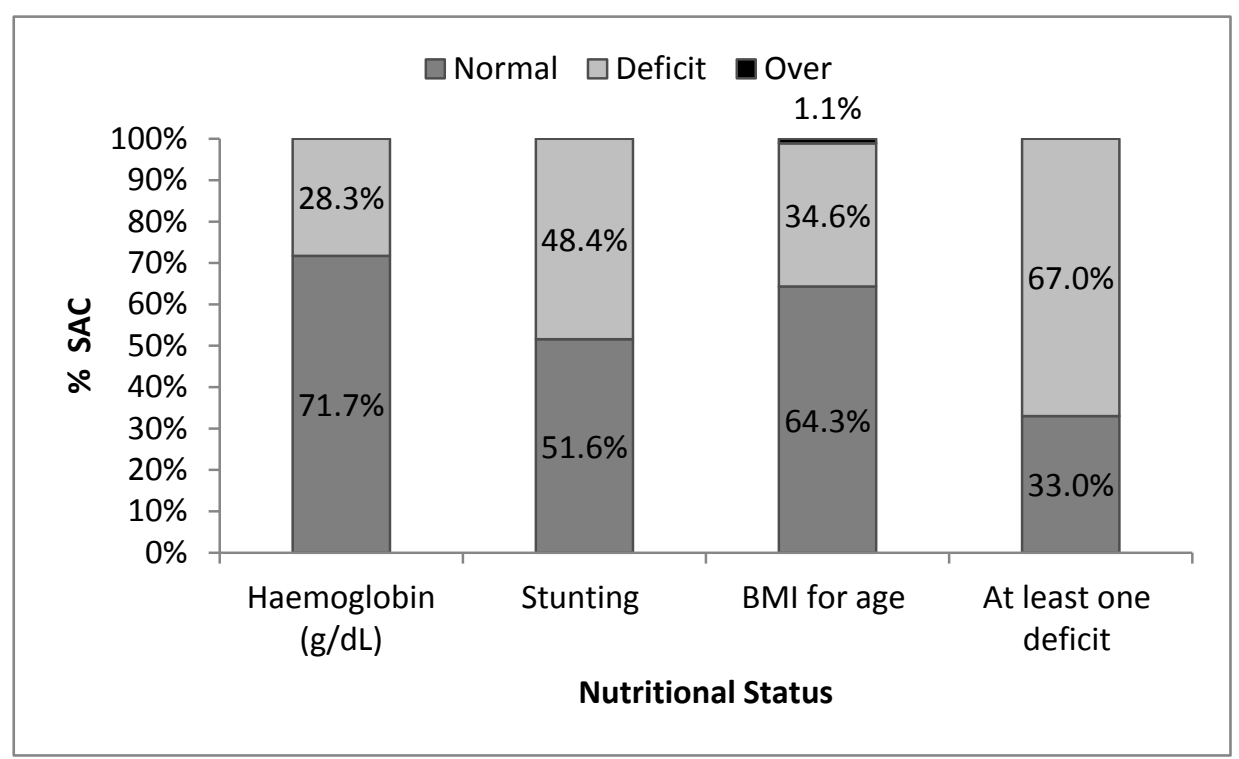

Figure 2. Prevalence of Anaemia, Stunting and Thinness and proportions of school-age children with at least one form of undernourishment

\section{Discussion}

\subsection{Nutritional Status}

The present study found a high prevalence of malnutrition among the school-age children. The prevalence of anaemia among school-age children was lower $(28.3 \%)$ than the national prevalence of $71 \%$ reported in 1995 (Agble, Bader, Solal Céligny, Palma, \& Dop, 2009). The prevalence of anaemia found in this study was however close to WHO global estimation on worldwide prevalence of anaemia 1993-2005. According to WHO (WHO, 2008), 25.8\% of the world's populace school-age children are anaemic. High rates of anaemia among school age children may be partly due to worm infestation (Osazuwa, Ayo, \& Imade, 2011). The Ghana Health Service had undertaken deworming exercise prior to the study and this may have ameliorated haemoglobin levels among the school children. Other studies in Ghana which were not on a national scale have also found anaemia prevalence of $70 \%$ among school age children (6-11 years) in Eastern region who were either enrolled or non-enrolled in schools (Fentiman et al., 2001), 30.8\% among children 6-12 years in a rural area in Volta Region (Egbi et al., 2014) and 25\% among 9 months to 11 years old vegans and matched non-vegan children in Central region of Ghana (Osei-Boadi, Lartey, Marquis, \& Colecraft, 2012).

Stunting was the most prevalent nutritional deficit (45.8\%) among school-age children in this study. An even higher prevalence of stunting was found among rural school-aged children in Ghana (52.2\%) by Danquah and colleagues (Danquah et al., 2012) among class 5 pupils attending schools with or without GSFP. In contrast, other studies have reported a lower prevalence of stunting 30.2\% (Chesire, Orago, Oteba, \& Echoka, 2008) in 
Nairobi, Kenya and 30.7\% (Mekonnen, Tadesse, \& Kisi, 2013) in Northwest of Ethiopia among school-age children. The differences observed between children from Kenya (Chesire et al., 2008) and present study may be attributed to regional differences: participants in the current study were from semi-rural setting; whereas in the Kenyan study was conducted in peri-urban area. Children from the Ethiopia study were from a rural region; however, the age group (6-12 years vs. 6-14 years) may account for differences in stunting levels observed.

Stunting was more pronounced among children 10 years and older than younger children (6-9 years). Similar results have been reported in Ethiopia and Kenya among school age children (Herrador et al., 2014; Mwaniki \& Makokha, 2013). Younger age associated with stunting may be due to the fact that these SAC may have had little nutritional deficit during their pre-school age. Most nutritional interventions are targeted at preschoolers (Bundy, 2009). Considering most nutrition interventions are targeted at pre-schoolers which is a stage closer to younger SAC group, it is possible these younger SAC may have benefited from such interventions.

The prevalence of thinness among the school-age children in this study was $34.6 \%$; whereas, a lower prevalence has been observed among peri-urban Kenyan school-age children (4.5\%) (Chesire et al., 2008), and among participants and non-participants of GSFP in Ashanti Region (3.4\%) (Danquah et al., 2012). The higher prevalence of thinness observed in this study than elsewhere may be a result of different age groups. Although Danquah et al., (2012) study was conducted in a rural setting of Ghana, the participants were older 9-17 years, whereas; this study had 6-12 years old children. There were more adolescents in Danquah and colleagues' (Danquah et al., 2012) investigation. Higher stunting observed in Danquah and colleagues' investigation as compared to the current study could account for lower thinness, since BMI for age is based on weight to height. Overweight and obesity was not a problem in this population of SAC. In contrast, other studies suggest that overweight and obesity may be a growing concern among SAC. In a survey of 1373 Malaysian primary school age children (9-10yrs), 16.3\% of them were overweight and 6.3\% were obese (Zaini, Lim, Low, \& Harun, 2005).

There was a high prevalence of malnutrition with nearly 7 out of 10 of the school-age children interviewed with at least one nutritional deficit. In Pakistan, Mian and colleagues reported that 4 out of 10 of school-age children had at least one nutritional deficit. Nutritional status indicators measured in the study (Mian, Ali, Ferroni, \& Underwood, 2002) were underweight, stunting and wasting and not anaemia status. Joshi and colleagues (Joshi, Gupta, Joshi, \& Mahajan, 2011) found $1 \%$ of 789 Nepalese children to be either stunted or wasted. Unlike the Nepalese and Pakistan study, we included anaemia status in assessing at least one nutritional deficit. This may explain the high level of malnutrition observed in our study.

4.2 Energy and Nutrient Intakes of School-Age Children and Contribution of School Feeding Meals to Total Intakes

Most of the school-age children had adequate intakes of energy and selected nutrients except for calcium. Calcium intakes were very low among school-age children in both the GSFP and NSFP. This finding corroborates Henry and Chapman (Henry \& Chapman, 2002) assessment of low calcium intakes in African populations of 300-400 mg/day which is well below the recommended daily intakes. Low intakes of food groups with calcium-rich food sources (green leafy vegetables and dairy products) among the children may explain their low levels of calcium intake. Participants in the NSFP had significantly higher intakes of energy, protein and zinc than the GSFP children. Studies that have compared dietary intakes of participants and non-participants of school feeding programmes have generally reported higher dietary intakes among participants than non-participants of school feeding programmes. Ahmed (Ahmed, 2004) reported that participants of school feeding programmes in rural areas had a higher intake of energy than non-participants. Among 320 Kenyan primary pupils, it was observed that participants had higher intake of energy $(2089 \pm 12.41 \mathrm{kcal}$ vs. $1841 \pm 15.68 \mathrm{kcal} ; P<0.05)$ and protein $(58 \pm 7.5 \mathrm{~g}$ vs. $40 \pm 2.4 \mathrm{~g} ; P<0.05)$ than non-participants (Musamali, 2007). In the present study only children participating in one of two school feeding programmes were assessed without comparison to non-participators.

The superior contributions of the NSFP meals to the children's energy and nutrient intakes may be because of the larger portion size of meals served to the children. In Bangladesh, fortified biscuits are used as a school feeding programmes mid-morning snack and this meal only contributes to $16.4 \%$ (urban communities) and $14.8 \%$ (rural communities) of energy intakes (Ahmed, 2004). The energy contribution of the meals provided by the Bangladesh school feeding programme (Ahmed, 2004) were less than the NSFP meals which contribute to more than $25 \%$ of daily intake; albeit, they match the GSFP meals (Danquah et al., 2012). Danquah and colleagues (2012) assessed the energy and nutrient content of meals served by the GSFP in three schools and reported a mean energy content of $460.4 \pm 30.1 \mathrm{kcal}$ which did not supply the required $30 \%$ of daily energy and nutrients. In the present study, the energy content of the GSFP meals was significantly lower ( $295 \pm 94 \mathrm{kcal})$ than what 
Danquah et al., (2012) reported and supplied less of the recommended energy and nutrients of children (Bhatia, 2013; Food and Agriculture Organization [FAO], 2004).

Based on FAO guidelines (Burgess \& Glasauer, 2004), the children in this study had adequate meal frequency. The children's eating events consisted of three meals and one snack daily. Most of the children's eating events occurred at home. Consistent with this finding, Olusanya (Olusanya, 2010) reported that a higher percentage of meals consumed by rural Nigerian primary pupils (1-3) were at home (breakfast: $89.7 \%$, lunch: $100 \%$ and supper: $100 \%$ ). In this same study of Nigerian pupils, the source of meals was mostly home prepared (breakfast: $72.4 \%$ and $100 \%$ for both lunch and supper) (Olusanya, 2010). In this present study, more than $80 \%$ of school-age children were given money for food on school days and the average amount of 70 pesewas (0.36 USD in 2013) that they received was equivalent to the cost of meals served by NSFP per child. The meals served by NSFP contributed more energy and selected nutrients than GSFP with a lower cost of 40 pesewas (0.21 USD in 2013). About $30 \%$ of the Nigerian pupils did not receive money for school on school days. Thus, it is not surprising that school-age children in this study ate more non-home prepared food than the Nigerian pupils whose major source of meals were home prepared.

Consistent with typical African diets (Oniang'o, Mutuku, \& Malaba, 2003), all school-age children interviewed reported eating food belonging to grains, roots and tubers groups. Food groups that were less consumed by school-age children included organ meats, dairy products, eggs and dark green leafy vegetables. Olumakaiye (Olumakaiye, 2013), also found a similar result among 600 school-age children at South Western Nigeria school-age children involved in the study were less likely to consume food groups such as organ meats, milk and milk products, eggs, and vitamin A rich fruits and vegetables (Olumakaiye, 2013). At the time of the study, local fruits such as black velvet tamarind (locally called Yooyi), dawadawa fruit snack, and mangoes were in season and readily available and may explain the high prevalence of fruits intake among the study children in contrast to consistent documentation that children are less likely to eat fruits and vegetables as part of their diet (Lock, Pomerleau, Causer, \& McKee, 2005). Approximately $75 \%$ of the children in the current study compared to less than $5 \%$ of Nigerian school-aged children reported eating fruit in the past 24 hours (Ene-Obong \& Ekweagwu, 2013). It is worth noting that the fruits that the participants ate were mostly black velvet tamarind (known locally as yooyi), dawadawa fruit snack and mango. The aforementioned fruits that were eaten by the children were in season and widely available in the community and school-age children plucked them by themselves to eat. The fruits that they had to buy such as bananas, oranges and apples which were not locally available were less consumed among the participants due to the cost. Almost all (99\%) the school-age children ate an animal source food in the past 48 hours compared to $2 \%$ of school-aged children (aged 5-14 years) in rural Nigeria reported by Ene-Obong and Ekweagwu (Ene-Obong \& Ekweagwu, 2013). Most school-age children involved in this present study were either part of NSFP or GSFP. NSFP meals observed during the data collection period were always accompanied with fish, chicken, egg or sausage. GSFP also had anchovies added to the meals on some days so there is a likelihood of children consuming an animal source food. Another possibility is that most of the foods that school-age children reported eating based on the 24-hour recall at school were with an animal source food. School-age children at GSFP site reportedly bought fried yam with chicken or sausage mostly at break sections of school hours. Also considering the fact that most school-age children ate at least a meal at home in a day, it is likely caregivers added an animal source food.

Dietary diversity score, DDS for GSFP participants was $5.46 \pm 1.00$ and NSFP participants was $5.51 \pm 1.15$ based on 9 food groups proposed by FAO (Kennedy et al., 2011). While assessing the impact of GSFP in 4 districts in the Central region of Ghana, Martens (Martens, 2007) observed that GSFP increased the DDS of the participants of school feeding programmes by $1.0 \pm 0.8$ (Martens, 2007). Our study found school feeding meals included vegetables like okra and cabbage as well as legumes such as beans which may have the potential of increasing dietary diversity scores if such foods were absent in the diet of school-age children.

An important strength of the present study is that it contributes to the limited data available on the dietary intakes and nutritional status of school-aged children in Ghana. It also provides some insights into the nutritional quality of the two categories of school feeding programmes. A methodological weakness of our study is not using the same sample selection techniques at both schools. This was due to the unequal number of school age children at the two schools and hence we invited participation from all the 125 school-age children at the NSFP school and we invited a random selection of $50 \%$ of the 300 children found at the GSFP to participate in the study.

\section{Conclusion}

There was a high prevalence (67\%) of undernutrition (either stunted anaemic or thin) among school-age children participating in NSFP and GSFP. At least 3 out of 10 school-age children were anaemic or thin (low BAZ) and 
about 5 out of 10 were stunted. The age of SAC was a significant predictor of stunting. Meals served by both programmes should be reviewed to ensure they meet at least $30 \%$ of recommended energy and micronutrients intake. Since school meals provide the majority of nutrition for school-aged children, the potential to mitigate malnutrition lies with school and community programmes to enhance nutrition.

\section{Competing Interest}

The authors declare no conflict of interest.

\section{Acknowledgements}

The authors thank Prof. Anna Lartey for granting permission to use RIING Nutrient Database, Dr. Seth Adu-Afarwuah, Mr. Boateng Bannerman, Phinehas Adjei, Esther Sam, Uriah Smith Karikari, Nathaniel Adu Adjei and Prince Anyitomise Kelly for their contribution to data collection and management.

\section{Funding Information}

This work was partially funded by Prembaf Ghana, an affiliate of Prem Rawat Foundation. Prembaf Ghana did not have any role in design, analysis or writing of this article.

\section{References}

Abotsi, A. K. (2013). Expectations of School Feeding Programme: Impact on School Enrolment, Attendance and Academic Performance in Elementary Ghanaian Schools British Journal of Education, Society \& Behavioural Science, 3(1), 76-92.

Adelman, S., Gilligan, D., \& Lehrer, K. (2008). How effective are food for education programs? A critical assessment of the evidence from developing countries International Food Policy Research Institute. http://dx.doi.org/10.2499/0896295095FPRev9.

Afridi, F. (2010). Child welfare programs and child nutrition: Evidence from a mandated school meal program in india. Journal of Development Economics, 92(2), 152-165. https://doi.org/10.1016/j.jdeveco.2009.02.002

Agble, R., Bader, E., Solal Céligny, A., Palma, G., \& Dop, M. C. (2009). Nutrition country profile for the republic of Ghana. FAO: Nutrition country profiles FAO.

Ahmed, A. U. (2004). Impact of feeding children in school: Evidence from Bangladesh. Washington, DC: International Food Policy Research Institute,

Arsenault, J. E., Mora-Plazas, M., Forero, Y., Lopez-Arana, S., Marin, C., Baylin, A., \& Villamor, E. (2009). Provision of a school snack is associated with vitamin B-12 status, linear growth, and morbidity in children from Bogota, Colombia. The Journal of Nutrition, 139(9), 1744-1750. http://dx.doi.org/10.3945/jn.109.108662

Best, C., Neufingerl, N., Van Geel, L., van den Briel, T., \& Osendarp, S. (2010). The nutritional status of school-aged children: Why should we care? Food \& Nutrition Bulletin, 31(3), 400-417. https://doi.org/10.1177/156482651003100303

Bhatia, R. (2013). Operational guidance on menu planning HGSF working paper series \#3. Retrieved from http://hgsf-global.org/en/bank/downloads/doc_download/347-operational-guidance-on-menu-planning.;

Bundy, D. A. (2009). Rethinking school feeding: Social safety nets, child development, and the education sector World Bank Publications.

Burgess, A., \& Glasauer, P. (2004). Family nutrition guide Food \& Agriculture Org.

Centers for Disease Control and Prevention [CDC]. (2015). About child and teen BMI. Retrieved from http://www.cdc.gov/healthyweight/assessing/bmi/childrens_bmi/about_childrens_bmi.html

Chesire, E., Orago, A., Oteba, L., \& Echoka, E. (2008). Determinants of under nutrition among school age children in a Nairobi peri-urban slum. East African Medical Journal, 85(10), 471-479.

Danquah, A., Amoah, A., Steiner-Asiedu, M., \& Opare-Obisaw, C. (2012). Nutritional status of participating and non-participating pupils in the Ghana school feeding programme. Journal of Food Research, 1(3), 263. https://doi.org/10.5539/jfr.v1n3p263

Egbi, G., Steiner-Asiedu, M., Kwesi, F. S., Ayi, I., Ofosu, W., Setorglo, J., ... Armar-Klemesu, M. (2014). Anaemia among school children older than five years in the Volta region of Ghana. The Pan African Medical Journal, 17 Suppl 1, 10. http://dx.doi.org/10.11694/pamj.supp.2014.17.1.3205

Ene-Obong, H., \& Ekweagwu, E. (2013). Dietary habits and nutritional status of rural school age children in 
Ebonyi state, Nigeria. Nigerian Journal of Nutritional Sciences, 33(1), 23-30.

Fentiman, A., Hall, A., \& Bundy, D. (2001). Health and cultural factors associated with enrolment in basic education: A study in rural Ghana. Social Science \& Medicine, 52(3), 429-439. https://doi.org/10.1016/S0277-9536(00)00152-0

Food and Agriculture Organization [FAO]. (2004). Dietary reference intakes. Retrieved from http://www.sochinut.cl/pdf/Recomendaciones/DRISummaryListing.pdf

Ghana School Feeding Programme [GSFP]. (2010). Snapshot of Ghana school feeding. (Presentation given to the 2010 Global Child Nutrition Forum held in Accra, Ghana.). Ghana:

Ghana Statistical Service [GSS], Ghana Health Service [GHS], and Inner City Fund [ICF] Macro. (2015). Ghana demographic and health survey 2014. Rockville, Maryland, USA: GSS, GHS, and ICF International.

Ghazi, H. F., Isa, Z. M., Aljunid, S., Tamil, A. M., \& Abdalqader, M. A. (2012). Nutritional status, nutritional habit and breakfast intake in relation to IQ among primary school children in Baghdad city, Iraq. Pakistan Journal of Nutrition, 11(4), 379-382. https://doi.org/10.3923/pjn.2012.379.382

Henry, C., \& Chapman, C. (2002). The nutrition handbook for food processors, Elsevier. https://doi.org/10.1533/9781855736658

Herrador, Z., Sordo, L., Gadisa, E., Moreno, J., Nieto, J., Benito, A., ... Custodio, E. (2014). Cross-sectional study of malnutrition and associated factors among school aged children in rural and urban settings of Fogera and Libo Kemkem districts, Ethiopia. PloS One, 9(9), e105880.

https://doi.org/10.1371/journal.pone.0105880

Inter Tribal Council of Arizona [ITCA] Training, (2012). Module 5: Haemoglobin Testing retrieved from http://itcaonline.com/wp-content/uploads/2011/10/Unit-3-Hemoglobin-Testing.pdf

Joshi, H., Gupta, R., Joshi, M., \& Mahajan, V. (2011). Determinants of nutritional status of school children-A cross sectional study in the western region of Nepal. National Journal of Integrated Research in Medicine 2(1), 10-15.

Kennedy, G., Ballard, T., \& Dop, M. C. (2011). Guidelines for measuring household and individual dietary diversity Nutrition and Consumer Protection Division, Food and Agriculture Organization of the United Nations. Retrieved from: http://www.fao.org/fileadmin/user_upload/wa_workshop/docs/FAO-guidelines-dietary-diversity2011.pdf

Kristjansson, B., Petticrew, M., MacDonald, B., Krasevec, J., Janzen, L., Greenhalgh, T., . . Shea, B. (2007). School feeding for improving the physical and psychosocial health of disadvantaged students. The Cochrane Database System Review, 24(1). CD004676. https://doi.org/10.1002/14651858.CD004676.pub2

Lock, K., Pomerleau, J., Causer, L., \& McKee, M. (2005). Low fruit and vegetable consumption. Bulletin of the World Health Organization, 83 (2), 100-108.

Martens, T. (2007). Impact of the Ghana school feeding programme in 4 districts in central region, Ghana. Wageningen University: Division of Human Nutrition (Thesis)

Mekonnen, H., Tadesse, T., \& Kisi, T. (2013). Malnutrition and its correlates among rural primary school children of Fogera district, northwest Ethiopia. Journal of Nutritional Disorders and Therapy S, 12, 2161-0509. https://doi.org/10.4172/2161-0509.s12-002

Mesfin, F., \& Berhane, Y. (2015). Prevalence and associated factors of stunting among primary school children in Eastern Ethiopia.

Mian, R. M., Ali, M., Ferroni, P. A., \& Underwood, P. (2002). The nutritional status of school-aged children in an urban squatter settlement in Pakistan. Pakistan Journal of Nutrition, 1(3), 121-123. https://doi.org/10.3923/pjn.2002.121.123

Mukudi, E. (2003). Nutrition status, education participation, and school achievement among Kenyan middle-school children. Nutrition, 19(7), 612-616. https://doi.org/10.1016/S0899-9007(03)00037-6

Musamali, B. (2007). Impact of school lunch programmes on nutritional status of children in Vihiga district, western Kenya. African Journal of Food, Agriculture, Nutrition and Development, 7(6), Retrieved from: http://www.bioline.org.br/request?nd07048

Mwaniki, E., \& Makokha, A. (2013). Nutrition status and associated factors among children in public primary schools in Dagoretti, Nairobi, Kenya. African Health Sciences, 13(1), 38-46. 
https://doi.org/10.4314/ahs.v13i1.6

Ndukwu, C., Egbuonu, I., Ulasi, T., \& Ebenebe, J. (2013). Determinants of undernutrition among primary school children residing in slum areas of a Nigerian city. Nigerian Journal of Clinical Practice, 16(2), 178-183. https://doi.org/10.4103/1119-3077.110142

Neervoort, F., von Rosenstiel, I., Bongers, K., Demetriades, M., Shacola, M., \& Wolffers, I. (2013). Effect of a school feeding programme on nutritional status and anaemia in an urban slum: A preliminary evaluation in Kenya. Journal of Tropical Pediatrics, 59(3), 165-174. doi:10.1093/tropej/fms070

Neumann, C. G., Murphy, S. P., Gewa, C., Grillenberger, M., \& Bwibo, N. O. (2007). Meat supplementation improves growth, cognitive, and behavioral outcomes in Kenyan children. The Journal of Nutrition, 137(4), 1119-1123.

Olumakaiye, M. (2013). Dietary diversity as a correlate of undernutrition among school-age children in southwestern Nigeria. Annals of Nutrition and Metabolism, , 63 569-569.

Olusanya, J. (2010). Assessment of the food habits and school feeding programme of pupils in a rural community in odogbolu local government area of ogun state. Nigeria Pakistan Nutrition Journal, 9, 198-204. https://doi.org/10.3923/pjn.2010.198.204

Omwami, E. M., Neumann, C., \& Bwibo, N. O. (2011). Effects of a school feeding intervention on school attendance rates among elementary schoolchildren in rural Kenya. Nutrition, 27(2), 188-193. https://doi.org/10.1016/j.nut.2010.01.009

Oniang'o, R., Mutuku, J., \& Malaba, S. J. (2003). Contemporary African food habits and their nutritional and health implications. Asia Pacific Journal of Clinical Nutrition, 12(3), 331-336.

Osazuwa, F., Ayo, O. M., \& Imade, P. (2011). A significant association between intestinal helminth infection and anaemia burden in children in rural communities of Edo state, Nigeria. North American Journal of Medical Sciences, 3(1), 30-34. doi:10.4297/najms.2011.330

Osei-Boadi, K., Lartey, A., Marquis, G., \& Colecraft, E. (2012). Dietary intakes and iron status of vegetarian and non-vegetarian children in selected communities in Accra and Cape coast, Ghana. African Journal of Food, Agriculture, Nutrition and Development, 12(1), 5822-5842.

Schaible, U. E., \& Kaufmann, S. H. (2007). Malnutrition and infection: Complex mechanisms and global impacts. Public Library of Science Medicine, 4(5), e115, 0806-0812. https://doi.org/10.1371/journal.pmed.0040115

World Food Programme [WFP]. (2015). WFP and school meals. Retrieved from http://www.wfp.org/school-meals/wfp-school-meals

World Food Programme [WFP] and United Nations Children's Fund [UNICEF]. (2005). The essential package: Twelve interventions to improve the health and nutrition of school-age children. Retrieved from: http://www.un.org/esa/socdev/poverty/PovertyForum/Documents/The\%20Essential\%20Package.pdf

World Health Organization [WHO]. (2008). Worldwide prevalence of anaemia 1993-2005: WHO global database on anaemia. Edited by de Benoist, B., McLean, E., Ines Egli, I. \& Cogswell, M. Retrieved from: http://apps.who.int/iris/bitstream/10665/43894/1/9789241596657_eng.pdf

World Health Organization [WHO]. (2011). Haemoglobin concentrations for the diagnosis of anaemia and assessment of severity. (No. WHO/NMH/NHD/MNM/11.1). Geneva: World Health Organization. Retrieved from: http://www.who.int/vmnis/indicators/haemoglobin.pdf

Zaini, M. Z., Lim, C. T., Low, W. Y., \& Harun, F. (2005). Factors affecting nutritional status of Malaysian primary school children. Asia-Pacific Journal of Public Health / Asia-Pacific Academic Consortium for Public Health, 17(2), 71-80. https://doi.org/10.1177/101053950501700203

Zeba, A. N., Martin Prevel, Y., Some, I. T., \& Delisle, H. F. (2006). The positive impact of red palm oil in school meals on vitamin A status: Study in Burkina Faso. Nutrition Journal, 5, 17. http://dx.doi.org/1475-2891-5-17

\section{Copyrights}

Copyright for this article is retained by the author(s), with first publication rights granted to the journal.

This is an open-access article distributed under the terms and conditions of the Creative Commons Attribution license (http://creativecommons.org/licenses/by/4.0/). 